\title{
STUDENT POLITICS IN URBAN TERNATE, NORTH MALUKU
}

\author{
Basri Amin $\bowtie$ \\ Department of Sociology, State University of Gorontalo \\ Permalink/DOI: http://dx.doi.org/10.15294/komunitas.v6i1.2946
}

\begin{tabular}{|c|c|}
\hline Article History & $t$ \\
\hline $\begin{array}{l}\mathrm{d}: \mathrm{D} \\
\mathrm{d}: \mathrm{Ja}\end{array}$ & \multirow{3}{*}{$\begin{array}{l}\text { This article examines student politics articulated by university students in } \\
\text { contemporary Ternate, North Maluku. The involvement of students in the political } \\
\text { arena in the region is mostly organized through regional (ethnic) organizations. The } \\
\text { larger context of such political process is decentralisation, which make religional } \\
\text { resource resources dominated by the state. At the same time competition among } \\
\text { local elites and ethnic groups flourish. This is the main background of a new } \\
\text { formation of group interests in local level --including local university students-- } \\
\text { to gain group advantages. The case of Ternate, North Maluku, is an example of } \\
\text { how groups of students organize their practical interests in the arena of politics by } \\
\text { exploiting youth associations and ethnic organizations. }\end{array}$} \\
\hline Key & \\
\hline & \\
\hline
\end{tabular}

\section{POLITIK MAHASISWA DI KOTA TERNATE, MALUKU UTARA}

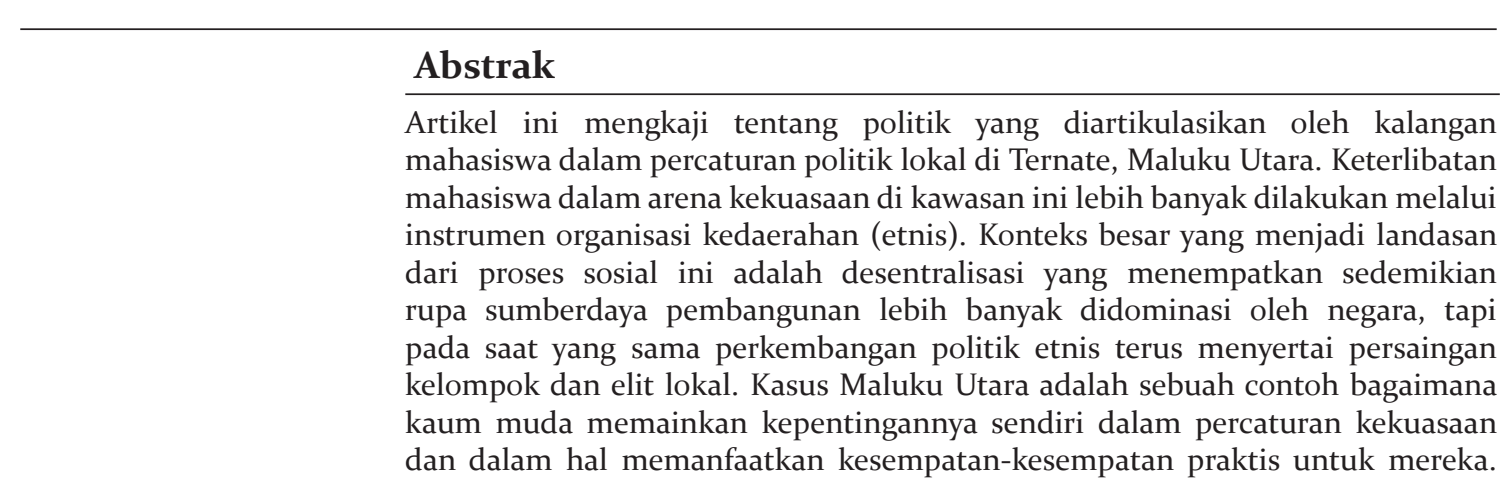

(c) 2014 Universitas Negeri Semarang 


\section{INTRODUCTION}

Geographically Ternate is a small town, but it is storing all political and cultural dynamics of North Maluku. In recent years, Ternate town can be located as a university town and will be the centre of education in North Maluku province. There are thousands of youths and students, mainly coming from Halmahera Islands, choosing Ternate as the main place to study or to find jobs. ${ }^{1}$ This is still in accordance with common image and legacy in which Ternate is generally regarded as the centre of education, economic services and urban life among the islanders in the northern Maluku archipelago (Kiem, 1993: 110). ${ }^{2}$

Student life is one of the important features of the youths in Ternate. Being a student has a symbolic meaning, a social status as well as a power in forming public or political participations in the larger social life in North Maluku. In a country where democracy is largely consolidated and economic development is struggling, youth participation in the political arena have been recognized quite well in social studies and public media (see: Jeffrey, 2010; Taufiqurrahman, 2010; Lee, 2008; Altbach, 1984). ${ }^{3}$

In the case of Ternate, despite large critical point of views among youths in Ternate --mainly university students-- to the new socio-political landscape in North Maluku, it should be noted that not all of their organizational activities could be said an independent ideal as the presence of strong ethnic interest and solidarity among

\footnotetext{
1 The number of university students in Ternate is quite large. Every year approximately $3000 \mathrm{stu}-$ dents apply at universities in Ternate town. They mostly apply at the state university of UNKHAIR and the private Islamic university of UMMU. In 2010, UMMU had about 8,00o registered students while UNKHAIR just over 6ooo (personal communication, Rector of Unkhair, May 2011 and Herman Oesman of UMMU, May 2011).

2 Kiem, C.G. (1993). Growing up in Indonesia. Youth and Social Change in a Moluccan Town. Bielefeld, Germany: Verlag Breitenbach Publishers.

3 Taufiqurrahman, M. (2010). Student Movement Close to Obsolescence. Jakarta Post, 14 March 2010. http://www.thejakartapost.com/news/2010/03/14/ student-movement-close-obsolescence.html (Retrieved on 10 August 2011)
}

student groups. However, it is important to recognize that organisations have a political function by which certain interest groups would be able to extend their interests in the public arena and in power relations through organizations.

This article examines primarily the dynamics of ethnic-based student organizations and their participation in public affairs, specifically in local politics. However, student involvement in such political maneuvers is not exclusive to Ternate town. It has historical roots particularly in postSoeharto Indonesia when the decentralization policy (since 1999) was implemented and from which new cities, districts and sub-districts were created and blossomed henceforth. As a consequence, government and political institutions are demanding human resources and public participation on the one hand, but on the other hand state capital flow into local levels of governance could trigger corrupt practices, informality and even other illegal practices (Klinken \& Aspinal, 2010).

Youth organizations are active part of the emerging 'pragmatic politics' where social factors such as ethnicity, class, religion and gender are strategically applied. Now what we need to explore is the processes, conditions, meanings and implications for youth lives by exploring their ways in the arena of power relations while they have a collective efforts in building youth identity or in forming such youth subjectivity. ${ }^{4}$

4 Beside ethnic elements that influence Ternatan student life, religious ties also play a significant role in post-communal conflict of 1999/200o. As can be seen since 2001, Muslim (female) students in Ternate schools have been obliged to wear the jilbab (head veil) during school hours. National organizations such as Hizbut Tahrir (HT) (Liberation Group) and KAMMI (Kesatuan Aksi Mahasiswa Muslim Indonesia, United Action of Indonesian Muslim Students), have progressively conducted their activities in Ternate such as giving out khutbah (sermon) pamphlets in the main mosques and campuses, selling or promoting salafy books, recruiting new members, and conducting demonstrations to support the enactment of Islamic principles (sharia). Another religious youth organization the Pemuda Muhammadiyah (PM) and Ikatan Mahasiswa Muhammadiyah (IMM) also actively conduct religious programs. Members of the $M u-$ 


\section{TERNATAN STUDENT ORGANIZA- TIONS}

In North Maluku, it seems that ethnic associations among youths became more apparent in the surface in recent years, particularly in the post-communal conflict in 1999/2000 and since decentralization movements are spread out to the regions. Contextually, this was also related to access by the youths, especially university students to local state agencies and companies, as new districts and cities were established in the wake of pemekaran (decentralization policy). In addition, new opportunities became available to them to access funds, resources and support from national and multi-national (mining and wood) companies in Halmahera. The reason behind this practice is because it is mandatory government policy that it is only through formal organizations that groups will be able to request state resources. Thus students are seeing this as opportunities for them, although in many cases student organizations also represent the local communities' concerns about public services and infrastructure. Organizations that are centred on ethnicity or territory (district, kabupaten) may be affective as they are thought to represent society.

Student organizations in Ternate, institutionally, can be characterized into three categories: firstly, ethnic or region-based organizations, secondly, national student organizations, and thirdly, interest-associated organization (such as discussion groups, study clubs, etc). ${ }^{5}$ However, organization is entered by students with different motivations and interests, and each organization

hammadiyah generally come from North Halmahera, and are mostly students at the University of Muhammadiyah of North Maluku (UMMU).

5 Since 2008 , at least sixteen ethnic-based or territory-oriented organizations represent students in Ternate. They are mostly native Halmaheran. As far as I observed, university students or youth community of Makean-Makayoa (south Hamlahera) did not openly apparent in the current student organization in Ternate, including Generasi Muda Sultan Babullah/Gemusba), a youth organization of Sultan Ternate, although these organizations are pronounced to be involved in 1999 communal conflict (Bubandt 2004; Klinken, 2007, etc). has its own structure and character, types of tension or competition, although there is a common feature among them which I would call it "the culture of ethnicity" and a tendency for political manoeuvres.

For student organisations in Ternate, ethnicity is as strong as kampong identity, and that is relatively more complicated as each student. It was not only conditioned to strengthen the students' ethnicity but also their kampong or district as well. Therefore, I would argue that through organisations, ethnical sentiments are produced and reproduced, socially and institutionally. ${ }^{6}$ Ethnic based-organizations established by students are relatively solid due to their membership size, purpose, form of organization and aspiration. Unlike typical ethnic organizations, when students join a religious or non religious organisation such as pro-democratic movement associations or NGOs, their explicit aspirations are more diverse. As a result, public debates and internal factions always accompany their organizational and leadership activities due to their large membership, the branches of organisations and interests in the local state agency and politics.

At the practical level of student organizations, ethnic sentiments and feelings of parochialism within organizations are articulated pragmatically in order to negotiate financial support (to build a boarding house or to get scholarship or other kinds of demands), both from the local government and corporations. This is partly triggered by regional decentralization where the local government has authority to fund such undertakings as part of its regional development programs. This is implemented twice per year. Consequently, such negotiations have opened up opportunities for students

6 Due to the availability of more powerful and stronger organisation with a large access to the local resources specifically state funds, student organisations in Ternate are relatively accommodated by KNPI (National Committee of Indonesian Youth), a semi-state youth organization, in regard to using their privilege connections to the local government funds and facilities (place of meeting, local accommodations, etc.) 
and other groups to submit grant proposals to the local government for their own interests. However, this local budgeting process requires a formal organization for all groups in order to qualify and be considered. Many student organizations are based along district and sub-district of origin in order to apply for state funds. Student organizations based on region and ethnic background are largely accommodated by the local governments because government agencies tend to be very concerned about possible public criticisms from these organizations. Students can make a frontal pressure (demonstrations) on government offices, thereby attracting media coverage on issues of corruption and cases of failed local development projects in specific areas.

Kardi (21), the chairman of student organizations of Weda for example, said that they had a right to access state funds because they are the citizens who are pursuing higher education and therefore in need of support. Nowadays, according to Kardi, "we have a lot of money in the regions, in North Maluku, but still not managed well by government offices, and they seem unwilling to manage it properly for progress (pembangunan). We tend to enjoy the central government for us in the name of autonomy..."

Becoming a leader of ethnic or national organisation at the provincial and town level can be such an achievement for students. With this position, they can access facilities and better their (formal and non-formal) connections to the local government and local elites. For instance they can easily ask for funds to support their organizations' programs and costs including rentals and secretariat facilities and equipment (computers, desks, uniform, etc). When there is a student gathering at the national level (often held in Java or Sulawesi), they can apply for tickets and travel funds. Access to those resources is achieved through lobbying with government officers or other connections in the DPRD (parliament offices). Such connections and other forms of informal ties are important social capital because in government offices there are special divisions that manage financial support (bantuan sosial), namely the social bureau (Biro Sosial) and the office for youth and sport affairs (Dinas pemuda dan olah raga).

In the end, on the one hand student organizations have a 'financial interest' on government funds, but on the other hand they try to influence government business to be more transparent and effective. This conclusion is fairly relevant for many student organizations that are based on regional or ethnic backgrounds. In contrast, youth organizations that are labeled as national and religious organization for instance HMI prefer to get funds and other support from their alumni networks. Such networks are very informal, and they can, at any time, access funds and facilities from the provincial government or regency and city government.

I argue that student activists create both capacity and strategy in pursuing their interests. By capacity, I mean the condition by which students have an ability to approach and produce certain opportunities in their common lives, very often in relation to local government agencies and elites in order to gain advantages. By strategy, I refer to the ways in which students use their organizational means to create significant social spaces that allow them to be recognized and be respected by the public and the state.

\section{ETHICS-BASED STUDENT ORGANI- ZATION AND DECENTRALIZATION ERA}

This section will start briefly on how Ternatan students created and sustained their ethnic concerns as a practical ground for establishing organizations and as a source of aspiration. I argue that student organizations reflect youth agency in forming representation and in inventing interests demanded by local people. This is precipitated by lack of state services at the local level of society. This is the defining (structural) arena in which students address their organizational concerns by using the ethnic marker. In this respect, I argue that ethnicity is not a rigid phenomenon in matters concerning collective identity but a symbol of societal demands that practically has an anxiety factor in a region of ethnical plurality like North Maluku. 
What I found in Ternate is that "student life is very busy and messy", particularly concerning organizations. I see that youths become vulnerable when they involve in local practical politics particularly in their role as active creators of ethnic- and regional-based organizations. ${ }^{7}$ Ethnic sentiment and local rivalry are being triggered by the decentralization policy in Indonesia. This has also ushered in competition arenas for all kinds of groups to stake their claims in public spaces, negotiate recognition and demand. When the competition for capital and political positions takes place, primordial sentiments such as ethnicity, religion, adat (custom, tradition) and any kind of traditional ties are invented or exploited (Henley \& Davidson, 2008; Nordholt, 2004; Machmud, 2013). In this context, students use this structural opportunity to participate in political affairs as well as to gain access to state capital in order to fulfil their practical (collective) needs,

7 As I recorded in 2008 and 2013: (1) Djaringan Mahasiswa Nuku (Djaman-Tidore Halteng); The Nuku Student Networks (Tidore); (2) Himpunan Pelajar Mahasiswa Hal-Sel (Hipma-Halsel), Student Association of South Halmahera; (3) Himpunan Pelajar Mahasiswa Loid-Bacan TimurHalsel, Students Association of Loid, East Bacan, South Halmahera; (4) Generasi Muda Oba (GeramOba), The Youth Generation of Oba; (5) Himpunan Pelajar Mahasiswa Oba (HIPMO), Student Association of Oba; (6) Ikatan Pelajar Samsumu (Ipelmas), Student Association of Samsumu; (7) Ikatan Pelajar Mahasiswa Gane Barat (Ipmagab), Student Association of West Gane; (8) Ikatan Pelajar Mahasiswa Indonesia Makian-Kayoa (IPMI-Makayoa Malut), Student Association of Makean-Kayoa; (9) Sentral Organisasi Pelajar Mahasiswa Haltim (SEOPMI-Haltim), Student Central Organization of East Halmahera; (10) Himpunan Pelajar Mahasiswa Islam Hal-Bar (Hipmi-Halbar), Islamic Student Association of West Halmahera; (11) Kerukunan Pelajar Mahasiswa Galela (KPMG), Student Association of Gelela; (12) Himpunan Pelajar Mahasiswa Tobelo, Student Association of Tobelo, North Halmahera; (13) Himpunan Pelajar Mahasiswa Obi Selatan (HIPMOS), Student Association of South Obi; (14) Himpunan Pelajar Mahasiswa Sula (HPMS), Student Association of Sula; (15) Himpunan Pelajar Mahasiswa Mano (Hipmo), Student Association of Mano; (16) Himpunan Pelajar Mahasiswa Ternate (HIPMAT), Student Association of Ternate; (17) Liga Mahasiswa Banau (LIMAU), Student League of Banau. while some (individuals/leaders) exploit their organizations as strategic vehicle for political positions and economic interests. ${ }^{8}$

Arguably, this reality is the local response to the structural change in Indonesian politics. This condition has an impact on young people, particularly students. They are able to organize themselves to participate in such 'messy politics' in local level in the name of civil society and democratic life but they could also create such demands to serve their practical interests. Here, students become the real actors in political sphere and power relations between state and society. Students also become the active mediator of democratic discourse in public arena.

In a larger context, the roles of ethnicbased organizations in Ternate transform itself to be a purposeful institution in terms of its ability both to access and to pressure local states. This process coincides with the emerging of "politics of identity", played mainly by local elites who try to capitalize on the political opportunity in the decentralization era. This was marred very much by tensions during rational transition to liberal democracy in Indonesian setting (Bubandt, 2004). For young people, especially students, Ternate town is the epicentre to experience such political roles in which student's agency is openly exercised. Groups of students from Halmahera for instance, receive highly "political experience" in Ternate and then make attempt to apply it in their region (Halmahera) once coming home to propagate good governance or local democracy, etc. This is one of the main rhetoric of students in local affairs. However, for the local power holders, the collective or organizational influence of

8 For a critical discussion on Indonesian decentralization, ethnicity, democracy, and local politics, see Schulte Nordholt (2004: 29-50) and Sidel (2004: 6o-70) in John Harris, Kristian Stokke and Olle Tornquist, Politicising Democracy, the New Local Politics of Democratization (2004); Schulte Nordholt, $\mathrm{H}$ and Klinken, G.V (eds), Renegotiating Boundaries: local politics in Post-Suharto Indonesia (KITLV, 2007); Erb, M and Sulistiyanto, P. (eds), Deepening Democracy in Indonesia? Direct Election for Local Leaders (PIlkada) (ISEAS, 2009); Klinken, G.V, (2009) 'The limits of ethnic clientelism in Indonesia', Review of Indonesian and Malaysian Affairs, vol. 42, no.2, pp. 35-65. 
student and the construction of ethnic interests had been a moving domain.

Three below examples of political moments might point out this notion:

- In the local Governor election in 2007 and 2013, there were around hundred university students of central Halmahera given free transportation fee by the regent to go back to their home to be his voter with an expectation that they voted for governor candidate;

- Students' boarding house of Weda in Ternate was paid each year by the government of central Halmahera district, 15 million per year, after students of Weda made demonstrations, demanding boarding house facility for them, and eventually is approved;

- One student boarding house in Gambesi (southern Ternate) was used by student community from north Patani region. The house was built by a wood company in central Halmahera;

- During the Mayoral elections in 2010, it was reported that some student organizations and ethnic-affiliated groups were involved campaigning for mayoral candidates. ${ }^{9}$

The above cases show how new poles in the organizational life of students in Ternate indicate their practical interests and how to fulfil them. Organizations and ethnic affiliations are two sides of one coin which easily used when there is a 'collective demand' and local circumstances toward local politics, state budget or companies. Since the decentralization significantly facilitated the democratic spheres in provincial and town levels, this comes with advantages for young people to involve themselves in and connect their interests to the local political

9 In this case, I noted that youth groups of Tidore Island had important roles in mobilizing such ethnic clientelism since the strongest candidate was a Tidorean senior bureaucrat in Ternate municipality who has been involved in the social organization of Tidorenese in Ternate. In the end, the election was won by a Tidorean (bureaucrat) and his partner, a northern-Ternatan businessman --supported by Sultan of Ternate. processes and the elite that are in charge.

Student and youth organizations have benefited from the implementation of regional autonomy (pemekaran) in North Maluku, but the stories of students' involvement in autonomy discourse and in local politics are quite ambivalent, as there are a number of criticisms directed at student organizations regarding the pemekaran movement. On the one hand they encourage the establishment of new regional autonomy as means to open up opportunities to access public goods and services and getting new jobs (especially as state civil servants) but on the other hand they also actively oppose the ideas of pemekaran if such a system only benefits the local elites (elite bureaucrats or politicians).

In fact, students have always been expressing their moral claim in Indonesian politics. In the context of decentralization, however, it can be noted that the pemekaran (decentralization) movement in the provincial and district level was pioneered by activists from youth organizations particularly provincial students. During my fieldwork in 2008, I noticed how the new regency of Kabupaten Morotai was promoted through public demonstrations in Ternate with the victory finally celebrated by other kampong youth organizations of Morotai Island endorsement from pemekaran-supported organizations in Ternate (October 2008).

Why are demonstrations popular in Ternate? Broadly speaking, activists and political groups have easy access to gain attention from the national media since media networks are concentrated in Ternate. It is also a strategy of the local elites to be in the media limelight in order to communicate their public interests. In urban Ternate, there are a number of places where public meetings (in hotels, cafes, etc) and the media (radio, internet and printed media, etc) that can be used as arenas of political campaigns or public discourse.

Recently, students and regional-based youth groups expressed different points of views, since when suspected that certain local Regents have personal interests in the movement. I take one example from 
a student organization of Sula Islands that protested the creation of a new district announced by local politicians and the provincial parliament of North Maluku. When the Morotai Islands became the new regency, student activists and few kampong youth organisations of Morotai became very vocal and demonstrated in downtown Gamala and in the parliament office in Ternate. In contrast to this, in 2009 when the idea of pemekaran was proposed to islands in the Sula region (called Mongoli and Taliabu), groups of youth rejected the idea of autonomy; they regarded it as political manipulation by the local elite which is the Bupati (Regent) of Sula and his political cliques. Thus, the story of student politics in pemekaran movement in Ternate is not a single reality.

Here is a brief story of an appealing case. In 17 September 2009, two small islands (Taliabu and Mongoli) located in the island region of Sula, were proposed by the regent government of Sula and its local parliament (DPRD) to be an autonomous district separated from Sula regency. After reviewing that proposal, the DPRD of North Maluku province approved it and sent it to central government in Jakarta for final approval. During this process of approval and consultations serious public debates ensued among people in the region. Kampong youth groups and student organizations of Taliabu and Mongoli in Ternate town became very active players to protest the creation of the new regency.

I met some of those student activists and leaders of the regional student organizations of Sula in July 2010 as well as read an intensive publication on the debates in the Malut Post, a leading newspaper in North Maluku province. I noted that there were two organisations actively involved in the public debates using the local media to protest in Ternate. They were the Aliansi Pemuda Sula (APS) and the Himpunan Pelajar dan Mahasiswa Sula (HPMS) of Ternate. They fervently argued that "the pemekaran of new regency is a part of political manipulation by Sula Regent, Ahmad Hidayat Mus...”

These two organizations subsequently asserted that:

\begin{abstract}
"The idea of pemekaran of district is a political strategy by Ahmad Hidayat Mus to win the local/direct election in 2010. This is a political promise that is will be same with other of his promises, like to commit to build bridge and make free education and health programs in Sula, but it was never come true until now...All are just promises and promises," said the chair of APS Zulfi Umasangaji in the press conference in Neraca Hotel of Ternate..." (Malut Post, 7 October 2009).
\end{abstract}

It seems that their protest is genuine and right. In the case of a region which will be divided or expanded (pemekaran) for a new regency, there are a number of official requirements (by law) that should be fulfilled, for instance population data and basic facilities. In the Sula case, according to the APS leader, population and infrastructure data have been manipulated. For example, the government of Sula said that the population in Mongoli and Taliabu Islands is 50,000 when in fact both islands have only 10,000 inhabitants. It was to such argument that the chair of APS considered it as a manipulation by the Regent in order to gain a popular support for the new local election.

According to Zulfi, the population data was intentionally exaggerated to fulfil a technical requirement of pemekaran can be approved by central government in Jakarta. Another manipulation, according to Zulfi, was the infrastructure in Mongoli and Taliabu, for instance the availability of banks and local financial institutions. The fact is there is no bank operating in the region as the number of people is relatively small. It was falsely reported that there were banks operating in those islands. Zulfi's objections were quite substantial and attracted public interest and thus were reported by the print media in Ternate. He even went to the point of saying that "the Regent of Sula has lied to people of Sula for his political interest to win the election..."(Malut Post, 7 October 2009).

The above cases illustrate that student voices in politics are mainly expressed through organizational action and public 
media. In this respect, students became political actors because they have to change the legitimacy of such state power and to influence orientations of local public policies. It is also clear that regional autonomy in North Maluku has significantly situated Ternate town as the centre of political and cultural contestations, where the youth actively involved in connecting or challenging local elite agendas, or vice versa, and the youth use their access to the states or local elites to negotiate their particular (collective) interests.

This study offers two suggestions: firstly, young people exercise their political manouvers through student organizations and any kind of political networks, and secondly, students could negotiate their idealism and practical interests with the local power (the state, political elite and companies) in order to realize their collective needs. In the following section I will discuss these issues in order to explain the reasons, chosen mechanisms and the outcomes of the involvement of student organizations in local politics.

\section{EXERCISING POLITICAL ENGAGE- MENTS AND PATRONS}

My ethnographic data show that students and youth organisation in Ternate plays important roles as they become part of 'political infrastructure' to increase the popularity of their seniors or patrons and to generate networks of supports for their political and economical interest. In the competition of general election (pilkada) for province, city or district leaders for instance, the activists of student or youth organisations often perform in political campaigns, or when conflict arouse, they become an organizer of strikes or massive demonstrations, including when giving pressure to political party, media, the local government and other state institutions (police, court, etc).

I observed in 2008 how students in Ternate organized demonstrations actively. Usually they choose government offices, police, and court as the location of strikes. But before, they occupy downtown stree- ts to hold rallies in order to get people and media attention, hundreds of posters are copied and distributed (to bus drivers, ojeg passengers, spectators, journalists, etc) when demonstration is taking place. The demonstration is usually about government corruption but sometimes just to put pressure on certain high-rank officers in government offices when they are suspected of corruption or fail to implement government decisions and policies. ${ }^{10}$

It is surprising to note that those who are in the state bureaucracy tend to be afraid of student demonstrations. And therefore, some of them (who had a higher level of position in office) try to create such networks to ethnic-based student organisation or other national youth organisations such as HMI or PMII which have a significant members and strong leaders. In fact, some local bureaucrats and political figures become such an informal "boss" for student groups. This phenomenon can be called 'patrons' of student organizations, and even exists on personal levels of student leaders. ${ }^{11}$

Network and patronage are key elements that are driving student organizations' role in local politics. However, the mechanisms that produce such network and patronage are likely to be related to the existence of ethnic and political interest among elite and middle class groups. Socially, the number of new local elites emerged significantly during decentralization and applies to North Maluku province where towns and districts flourished since 2000. Most of the new local elites are university alumni having studied outside the region, particularly in central Java, Ambon (central Maluku), Makassar and Manado in Sulawesi. They were commonly active in (national) student orga-

10 At this moment, corruption is seemingly a frightening issue in local level and everywhere in Indonesia. Beside this, mass demonstration is also campaigning transparency of government policy to build local infrastructure, education and health care.

11 The phenomenon of "bossism" and local patrons in the context of Indonesian politics examined by John Sidel (2004) 
nizations such as HMI, PMII, and Muhammadiyah, but some of them are involved in ethnic organisations. Thus, not surprisingly, they can easily connect with students' world and get along well with them when they return to Ternate. Moreover, they are treated as senior by students in Ternate and go on to play the role of 'patron' or 'connector' to the power structure in North Maluku. Each student organisation has their own (alumni or senior) networks, so there is always a sense of competition among senior-junior networks of one organisation with another, particularly when certain political events occur.

On a daily basis, students would address their senior who now has a position in the bureaucracy, company, media, NGOs, or in local politics as 'Ko', which means "old brother". The use of this address signifies respect and is an indication of closeness in cultivating networks of patrons in the social and political arenas. In the same context, for national organisations such as HMI or PMII, students address their seniors as Abang which means respect and personal closeness as well as a signifier of such egalitarianism in the relationship. I have noted that many parliament (DPRD) members and bureaucrats in North Maluku, in Ternate town and other regencies have backgrounds in student organisations. They are well trained to speak, and to create public forums, public campaign, debates, etc. They are also very familiar with popular issues such as democracy, governance, development, education, health, infrastructure, etc. But all these are rhetoric with empty promises during political campaigns.

\section{ETHNIC ORGANIZATION AND THE NARRATIVE OF ASRAMA (DORMI- TORY)}

Ethnic symbol is as strong as kampong identity for student organizations but that is relatively more complicated since each student is not only situated or conditioned to strengthen his/her ethnicity but also his/ her kampong. It seems that through organisations, ethnic sentiments are facilitated or reinvented emotionally and institutionally. The social and institutional atmosphere surrounding ethnicity has been significantly in existence in Ternate since 2000, following the post-communal conflict of 1999 where communal consciousness among locales in North Maluku first emerged.

Students have a variety of reasons to join organizations. Many feel that organizations have political functions and a social arena to pursue common interests such as ethnicity and regency. This is described by Ahmad (22):

"I chose to become a regular member in the student organization, because if I did not enter the organization, my friends from my kampung are always told me that I am not loyal to support the development of my region (South Halmahera)...most of my friend believe that the organization has the power to urge the government to create development programs to help our society, especially in education, health and infrastructure (roads) in the island. If we work with an organization, students in particular, the government will respect our ideas, because we are an independent group and our numbers are so many...and we are the youth who dared to speak the truth openly. Now everybody knows that political elite cannot be trusted at all. They have received a lot of protest because they seem to ignore people's problems...They are deaf. Well, the students are assigned to voice out the problems, including our needs too...For us, it is very difficult to get a job and school supports form the government, so we must remind them..."

Just as student organizations involve in political participation at the local level they also engage in ethnic and regional issues as symbols of collective pursuits. At the practical level, student organizations are a means to apply pressure at local governments and large companies to support their needs such as securing rooms in dormitories at educational institutions. As a matter of fact there are fewer dormitories to accommodate the large number of students so there is always competition among students.

Wardi, a 22-year old young man from Tobelo (North Halmahera) related to me the role of ethnic-based organizations. He said: 
"For one year I have joint HIKMAT (Himpunan Komunikasi Mahasiswa Tobelo), the communication forum for Tobelo students. Within the organisation it is listed about 120 cadres who are students and the regular member of the HIKMAT. The organisation was established under the agreement of students from Tobelo to discuss social problems of our region. Our problem is that we have no boarding house yet (asrama), and for this matter we are still in the process of lobbying our government to give student asrama for us. Our strategy is, first, sending proposal asking the government to build an asrama. Then, we organize all members of HIKMAT and accommodating their aspiration and we write a special letter and petition to pushing government of North Halmahera in Tobelo to be more aware about students' need of boarding house in Ternate"

For migrant students, asrama makes it easy for them to rent rooms with a low price compared to regular rooms rented by local people or housing enterprises around the campus area. There is a popular view that staying in asrama will make them more comfortable and less susceptible to home sickness as they live together with their compatriots.

During the last five years, ethnicbased boarding houses (asrama) emerged significantly. Some boarding houses have labels on small boards in front of the house (papan nama asrama), indicating the name of the region where the student occupants are from. In other cases, students rent houses of local Ternatans and use them as temporary secretariat for their organizations.

I will present a specific case to show how students label their asrama to be associated with their ethnic or regent backgrounds. Almost all of my Halmaheran informants in Ternate agreed to use the name of their region of origin, which is commonly associated to their ethnicity, to be put up in front of their boarding house. This way, they can show that the money they obtained from the local government has been used properly to rent an asrama for Halmaheran students. Students who reside in asrama said that they were proud to stay there. Be- side the lower cost they are paying monthly compared to staying in local boarding houses, they can, at any time meet local government officers, local parliament members or their seniors for meetings and group activities.

Physically, the asrama itself, is government property and students are given user rights. The user rights restrict them to dispose the property at their own will. All asramas built by the local government are publicly funded and the official process is complicated for instance for the buying of land, the company which will be contracted to build the asrama, and the total funds to be approved by the local government and the local representative (DPRD). Given these bureaucratic mazes, student organizations go out of their own way to apply pressure at the state agencies to fast track the process and sometimes they end up with such big demonstrations.

But the narrative of asrama has been triggered by competition among student groups and even at individual level. For example, in 2007/2008 students from the district of Central Halmahera were competing with one another to acquire support from the local government and the multinational companies to build an asrama for them. The problem was the students were divided into organizations based on three sub-districts that represented their place of origin. These sub-districts were Gebe, Weda and Patani. The conflict started when the Aneka Tambang (ANTAM), a mining company in Halmahera, built a boarding house in Ternate which was immediately claimed by the student organization of Gebe. This organization argued that the ANTAM operated in their sub-district territory (Weda) and not in other sub-district in Central Halmahera. This claim was seriously protested by other student organizations of Weda (Ikatan Mahasiswa Weda), because they thought that the ANTAM was a company that operated at district and not at subdistrict level.

Farid (21), a leader of Weda student claimed: 
“The ANTAM is not a kampung's company but a regional company, even a national company. Thus, whoever students come from Central Halmahera automatically deserve that boarding house," complained by Farid, a student leader of Weda..."

This kind of competition in claiming occupancy of an asrama only emerged in recent years in Ternate. Consequently, the argument and the counter argument brought government and company officials as well as the local elite into the fray elite as mediators. Ultimately an agreement was reached that saw the local government being the facilitator in awarding temporary rented houses to student groups. ${ }^{12}$

Why do students collectively need organizations to deal with state financial support in Ternate? To answer this, we need to know the social background of students in Ternate. As I mentioned earlier, almost 90\% of students in Ternate come from outside the town of Ternate, especially from the islands of Halmahera. Their socio-economic background is almost from the lower class, as seen from type of jobs of their parents have (farmers and fisherman). In contrast, students who come from middle class families typically study engineering or economics. Middle class students rarely reside in asrama (dormitory) since for them the private atmosphere of a rented room is better and the price is not a problem at all.

Life in an asrama portrays features of different socioeconomic backgrounds of Ternatan students as well as their collective aspirations toward their future through higher education. Moreover, asrama is related to their concerns as a vulnerable group at least financially, although they have power in terms in organizing solidarity actions. Along this line of thought student organizations can be seen as strategic resources

12 In one occasion, Riman (21) and Herdi (22), activists of student organization of central Halmahera, namely Ikatan Mahasiswa Weda, said to me how they organized a demonstration in the regency office as their proposal about a request that the government should give financial support for their organization to pay the cost of a rented house used by students of Weda as an asrama (conversation, 10 July 2010). to bridge the practical needs and ideals of students and this has the potential to break through the financial difficulties they face as students.

Although migrant students have limited power economically, their collective participation in local political affairs and gaining access to state resources as groups, invoke a new form power that is being exercised in adaptive ways which they never imagined before prior to becoming a student. Ternate town and its universities provide such new experiences for students. In other words, the organizations become a means of liberation and access to the local power game in which students are able to show their adaptive strategies using asrama and establishing informal networks to access public funds and political mobilization. Nevertheless, organizations have triggered new forms of competition among students. On one hand access to state resources cannot solve all of their needs and on the other hand actual interests among organization leaders and their members are often different.

Now the next question is who are the prominent players of student actions in Ternate? It is the migrant students. They provide the social basis of why students could be significantly involved in the local political affairs in Ternate.

Migrant students in Ternate are the major push factor leading to demands for new spaces for communal activities and living. For instance, the need for dormitories and organizations increased sharply in the last five years. However, behind this practical circumstance, migrant students are also experiencing challenges since feelings of marginality still exist particularly for those who came from smaller islands in the Halmahera archipelago. So, to be able to start a living in the city of Ternate, they have to make emotional and social adjustments if they come to Ternate for the first-time. For them, the choice to study in Ternate is an option to start a new life in the city which is a new experience of living separated from their families. 


\section{MARGINALITY: SOCIAL BASIS OF ETHNIC ORGANIZATION}

Ternate has a long history of receiving migrants, particularly from Halmahera Island. In the 1970s, when secondary schools were limited in Halmahera, migrant students chose Ternate as a place to continue schooling. It was notably difficult because they had to struggle with many things in their lives, including finding housing and financial support since the geographical distance was challenging. The only transportation was wooden boats. Back then there was no bank or means of communication such as telephones and post offices.

For Halmaheran migrants, coming to Ternate to study has double features: finding ways to achieve a successful future and fighting off the perception of being a marginal group. This feeling of being marginal is rooted in their experience during their education in Ternate. Migrant youth stories are plural. For example, Irman (21) feels that young people from Halmahera coming to Ternate are often treated as mediocre by Ternatan youngsters. Halmeharan youth are often stereotyped or marked as lazy, naughty, often late arriving at school, etc. This treatment happens in class and during special school ceremonies. Teachers often comment cynically about Halmaheran students for instance when they arrive late at school.

As an example a Ternatan teacher once meted out a cynical comment to Darmin (23):

“dasar dari pulau panjang...tak mau majumaju....kebiasaan di kampung jangan lagi dibawa-bawa di sini...Kalian sudah harus berubah...Kalian sudah sekolah di Ternate..."

(Uh, this was your habits, the people from Long Island...your awful custom should be not brought to Ternate...You are here now, so you must change your habits...You have been studying in Ternate)

It seems that the choice to study in Ternate is more appealing to students co- ming from Tobelo ${ }^{13}$ where Islamic schools are quite popular for students from lower class backgrounds. Sity, a 21 year-old told me that people from Tobelo and north Halmahera, especially Muslims, mostly come to Ternate to study in Islamic schools, such as the Islamic Higher School (Madrasah Aliyah Negeri/MAN). They prefer this option because the tuition fees are cheap and the school is very generous to migrant students. This kind of school is largely subsidized by the central government (Department of Religion of Indonesia). Yet, the government thinks that religious schools are not popular among local Ternatans and people from middle class backgrounds. As a result, Islamic schools are perceived negatively and often labelled as 'schools without a future'.

Sity recalls some popular views among local people:

"You know...religious school is discarded
school...It's never a favourite one...when
you finished there, your options for jobs
are very limited, maybe only one, which is
to be a religious teacher or to be a lower ci-
vil servant in the department of Religion"
(recited by Sity (21), a Muslim girl from
Tobelo. ${ }^{14}$

At the end of the 1990s, the negative perception of studying in religious schools in Ternate was cast aside. At that time, the veil was considered traditional and exclusive. It was thought as inflexible toward Islam. It was no wonder then that MAN students could not follow the fashion trend among young people in Ternate, especially those

13 Tobelo is one of the centers of the communal conflict areas happened during the end of 1999 to 2000 (see: Klinken, 2004; Wilson, 2006; Duncan, 2008). In Tobelo, the number of Moslem and Christian community is quite balanced. In 2008, this city was governed by a Christian, while his deputy was a Moslem. It is a proof that these two communities want to live in peace and develop their town (personal communication, Oesman, 2010).

14 . “...Sekolah agama seperti sekolah buangan...pekerjaan yang bisa dipilih juga terbatas, paling hanya jadi guru agama saja, atau jadi pegawai rendahan di Departemen Agama..., Sity (21), Ternate, 21 Mei 2008. 
studying at public schools such as SMU and SMK where veils are rare. ${ }^{15}$ According to Sity, students at religious schools in Ternate were often called "kurang gaul people" (nonfashionable students) because they do not follow the secular life style trends.

In terms of school preferences, young people who were born and raised in Ternate town, including those migrants who came to Ternate from middle class families (civil servants or entrepreneur families), prefer to study in SMU (secondary state schools) or SMK (vocational school). In the past five years, SMK has grown popular because students can focus more on specific skills, such as accounting, foreign languages, secretarial studies, and information technology. It is a common image that they would easily get a job in the business world: banks, shopping centers, malls, companies, stores, vehicle dealers, or even supermarkets.

Nowadays, students are aware of their future in finding a job. Before the end of the 1990 within Ternate town, almost all religious schools did not have enough students to enrol. But this was turned around by migrant students coming from the other islands to study in Ternate. My key informant, Sity (21) said that the requirements to enter MAN Ternate were not as rigid as SMU or SMK. Consequently, Halmaherans who have low grades could be accepted in MAN.

Socially and emotionally, at first, Sity recalled that students of MAN hesitated to socialise freely like other students at school. Students of MAN are thought of as students who are learning pure religion so that they could not easily practice the modern life style for example in terms of fashion or music. In addition, when they go outside of their homed, like in downtown Gamalama or sweering beach of Ternate, they are not allo-

15 Since the end of communal conflict (2001), there is a kind of official instruction to the Muslim female student Muslim to wear a headscarf in schools. So when parents registered their children in school, they have to pay a package of Muslim dress and it must be used during school hours. Some of my informants stated that many students will took off her headscarf when it came home (Focus Group Discussion, 18 September 2008) wed to return home late at night. Thus, any kind of youth habits such as joining musical events, enjoying night life or hanging out with friends in the town are considered less religious among them and the northerners of Ternatans.

However, since the beginning of the 200os, such inflexible practices changed drastically. Nowadays, MAN and SMU students are relatively open to modern youth culture and lifestyle. ${ }^{16}$ Most of them are very familiar with cell phones, internet and music bands, as well as hanging around in Ternate's public areas and entertainment spots. They are also active in youth events such as band festivals and downtown gatherings. They are free to choose various kinds of veils, t-shirts, music, TV show, etc. MAN students have also learnt general (modern) subjects such as English language, math, and physics. They form music bands, sports teams, scouting groups, or other interest associations, etc.

The above stories of migrant youth, as represented by Sity, Darmin, Riri, Irman and Karim portrays the situation experienced by Halmaherans coming to Ternate to study. Beside the limited access to qualify for secondary schools in Ternate, they also have to fight off stereotypes expressed by their school mates and teachers. From their experience, we can say that there is a common belief and behaviour generated by local Ternatans that Ternate town is the center of development and the center of 'role model' for Halmaherans. Therefore, it is habitually expressed that Halmaherans have to follow the standard of living in Ternate if they want to be successful. Of course, such a claim is acceptable only to a certain extent since educational facilities are centred in Ternate,

16 Nowadays, it is popular the term "fashionable veil" in which it is designed more artistically and flexible. The image of veil as the symbol of stiffness and traditionalism is no longer thought among young people. Veil is now a unique style for young Moslems and it has been reproduced widely. Moreover, popular readings, magazines, radio broadcast, cellular services, tv programs, films and art activities colors the life of young Moslem generation in Indonesia (see: Hasan (2009) and Tantowi (2010). 
while Halmaherans generally have problems paying for tuition fees.

Since Ternate became an urbanized town, social gatherings have increased in size and frequency, facilitated by improved transportation and communication systems. That has clearly affected youth's outlooks in daily life and in ways they organize their social ties. Public space use also increased as evident in the increasing number of places where locals and migrants meet each other and exchange ideas, aspirations and preferences in school, dining, sport, entertainment or looking for places to relax such as in the shopping centers, seaside areas, cafés, etc.

For migrant students, they have such dependent status in terms of economic support from their families, but at the same time they have an interest in trying to be an 'independent actor' by pursuing a brighter future. Moving to the city and building a new life experience is a desirable dream for most young people. In the city, they can exercise much personal freedom from their family controls as well as experience the larger social arena, like the local political arena through their organizational participations and public criticisms.

A small but dynamic town, Ternate, in some way, has helped in the socialization and adaptation processes for young migrants coming to study in Ternate. The most adaptive group that is experiencing and negotiating this change are the youths. This is partly because of their large population and partly due to their mobility to encounter other groups and forming alliances and collective aspirations and practices.

\section{CONCLUSION}

This paper shows the interplay between student organizations, ethnicity and politics. Ethnicity is a crucial element in youths' lives in Ternate and it is rearticulated more pragmatically -through the establishment of region-based organizations - and exploited by for in the purpose of partaking in local affairs, and in politics in particular. Unfortunately, the position of youth is still easily co-opted by local elites and political patrons.

Studies about Indonesian students are mostly conducted in metropolitan settings where the dominant narrative of national politics is more visible in their political discourse (e.g. Lee, 2008; Kraince, 2000). In contrast, when students are studied at the local level, specifically in such peripheral areas, the dynamics of student life will show a multi-faceted picture, especially in the ethno-political arenas. For the case of Indonesia, the implementation of the decentralization policy has facilitated a typical power relation in which various groups' aspirations articulated in such a way and in different scales.

Nowadays, what is important to consider in Ternatan youth life is the fact that students are becoming active in exploiting ethnic sentiments in political affairs, but at the same time they also play a critical role in addressing major efforts to improve democracy and good governance at the local level. They are involved in creating more civic participations as can be seen in their participations in NGOs programs, the news media, etc.

Student life cannot only be understood as a transition period. Student itself represents a field of experiences and interests. Their busyness is always shifted every time, depending on situations that intersect with their ideas, emotions and routines. In a small town such as Ternate, the options to form a social pattern of student life that parallel the national pattern is unlikely to happen. This is shown in their actions and specific reasons that motivate them to involve in ethnic-based organizations. Students tend to remain flexible when they take part in regional politics. In this context, ethnicity becomes something that needs to be created and strategized with the intention of supporting typical narrative and interests, which are concerns of power relations.

\section{BIBLIOGRAPHY}

Ali, T. 2010. The Transformation of Muslim Women's Dress in Indonesia: Identity, Politics and Trend. MA Thesis. Leiden University.

Altbach, P.G.1984. Student Politics in the Third World. Higher Education (13): 635655. 
Aspinal, E \& Klinken, G.V. 2011. The State and Illegality in Indonesia. Leiden: KITLV.

Bubandt, N. 2004. "Menuju Sebuah Politik Tradisi yang Baru?: Desentralisasi, Konflik dan Adat di Wilayah Indonesia Timur". Antropologi Indonesia. 74: 12-27

Duncan, C. 2005. The Other Maluku: Chronological of Conflict in North Maluku. Indonesia 8o (October), Pp: 53-8o.

Hasan, N. 2009. Kaum Muda di Kota Provinsi Indonesia: Agama, Identitas dan Aktivisme. Unpublished research paper. Indonesia.

Henley, D. \& Davidson, J. 2008. In the Name of Adat: Regional Perspective on Reform, Tradition and Democracy. Modern Asian Studies.42 (4): 815852.

Jeffrey, C.2010. Timepas: Youth, Class and the politics of waiting in India. Stanford: Stanford University Press.

Kiem, C.G.1993. Growing up in Indonesia: Youth and Social Change in a Moluccan Town, Verlag breitenbach Publishers, Saarbrücken, Germany.

Kiem, C.G. 1993. Re-Islamization among Muslim Youth in Ternate Town, Eastern Indonesia. Sojourn. 8(1):92-127

Klinken, G.V. 2007. Communal Violence and democratization in Indonesia: Small Town Wars. London: Routledge.

Kraince, R.G. 200o. "The Roles of Islamic Student Groups in the Reformasi Struggle: KAMMI (Kesatuan Aksi Mahasiswa Muslim Indone- sia)", Studia Islamika.7(1):1-50 2003. "The Roles of Islamic Student Activists in Divergent Movements for Reform During Indonesia's Transition from Authoritarian Rule, 1998-2001.". Unpublished PhD Dissertation. Ohio University, USA.

Lee, D. 2008. The Origins of Our Future: Nationalism and Youth in the Indonesian Student Movement. $\mathrm{PhD}$ dissertation. Cornell University: USA.

Machmud, I. 2013. Kelompok Etnis dalam Pelukan Elite Lokal. Ternate: UMMU Press.

Nordholt, H.S. 2004. Decentralisation in Indonesia: Less state, More Democracy?. In Politicising Democracy, the New Local Politics of Democratization, Eds. John Harris, Kristian Stokke and Olle Tornquist. Palgrave NY: Macmillan. Pp: $29-50$

Nordholt, H.S. \& Klinken G.V. 2007. Renegotiating boundaries : local politics in post-Suharto Indonesia. Leiden: KITLV

Sidel, J. 2004. "Bossism and democracy in the Philippines, Thailand and Indonesia: towards an alternative framework for the study of 'local strongmen'". In Joh Harris, Kristian Stokke and Olle Tornquist (Eds) Politicising Democracy, the New Local Politics of Democratization. Palgrave N.Y: Macmillan. Pp: 6o-70.

Taufiqurrahman, M. (2010). "Student Movement Close to Obsolescence”. Jakarta Post, 14 March 2010. 